\title{
DIDÁTICA E/OU TECNOLOGIA?
}

\section{Didactique et/ou technologie?}

\author{
Sônia Cristina Vermelho*
}

\section{Resumo}

Nesse artigo procuro discutir uma possibilidade de relação entre a Didática e a Tecnologia, em particular aquelas que utilizam as imagens como veículos para os seus conteúdos. Essa relação, que em muitos países vem sendo tratada como Educação para as Mídias, é um esforço no sentido de promover uma formação docente que dê sustentação para um trabalho de formação crítica em relação às mídias, em particular à gramática visual, da qual lançam mão essas Tecnologias. O objetivo dessa busca, desse "casamento" entre a Didática e a Tecnologia, numa perspectiva claramente humanista e não tecnicista, é a consciência de que nossa sociedade caminha a passos largos para a sua própria barbárie, e que uma das poucas possibilidades que vislumbro é uma educação que privilegie a reflexão, a formação de um sujeito autônomo e livre, ou seja, de um sujeito capaz de transformar essa sociedade.

Palavras-chave: Didática, Tecnologia, Mídias, Educação.

\section{Résumé}

Cet article veut discuter la possibilité du rapport qui peut avoir entre la Didactique etla technologie, en particulier celle qu'utilise les images entant que moyen pour émettre des contenus. Cette relation dans beaucoup de pays s'appelle Education pour les Média. Il s'agit um effort pour donner une formation aux enseignants, lorsqu'ils utilisent les média. Le but de ce "mariage" entre les didactiques et la technologie, dans une perspective clairement humaniste et non technoloque, c' est d' arriver à la conscience du fait que notre société marche rapidement vers la barbarie, et done une des possibilities que je vois de changer cela, ce serait au travers d' une éducation qui donne lieu à la réflexion, à la formation d'un sujet autonôme et libre, c' est-à-dire à la réflexion, à la formation d'un sujet capable de transformer la société.

Mots-clefs: Didactique, technologie, médias, éducation.

* Professora do Mestrado em Educação da PUCPR.

Rua Guairicana, no 140, Uberaba, Curitiba - PR, CEP 81550-320.

E-mail: vermelho@rla01.pucpr.br 
Por um lado, cada época produz aqueles caracteres - tipos de distribuição de energia psíquica - de que necessita socialmente. Um mundo como o de hoje, no qual a técnica ocupa posição-chave, produz pessoas tecnológicas, afinadas com a técnica. (...). Por outro lado, na relação atual com a técnica, há algo excessivo, irracional, patógeno. Esse algo está relacionado com o véu tecnológico. As pessoas tendem a tomar a técnica pela coisa mesma, a considerá-la um fim em si, uma força com vida própria, esquecendo, porém, que ela é o prolongamento do braço humano. Os meios (...) são fetichizados porque os fins, uma vida humana digna, têm sido velados e expulsos da consciência das pessoas. (ADORNO, 1995, p. 118)

À guisa de introdução, gostaria de limpar o terreno no qual estou propondo essa discussão em torno da Didática e/ou Tecnologia. Primeiramente, e historicamente, quando se fala em Tecnologia e educação na história brasileira, é usual atrelá-la ao conceito de Tecnologia Educacional. Esse "campo" de estudos teve sua trajetória, numa certa medida, muito vinculada a uma perspectiva de uso da Tecnologia na educação de inspiração estadunidense e, mais ainda, embutida numa pedagogia: a tecnicista. Nessa perspectiva, assistimos a algumas mudanças ou encaminhamentos teórico-práticos de uso das tecnologias que ora entendiam a Tecnologia Educacional como uma área que se ocuparia da educação como um sistema, e, portanto, caberia a ela pensar a melhor forma de funcionamento desse "sistema" educacional - esse foi um momento que se desenvolveu por volta dos anos 1950/1960 - ora, a Tecnologia Educacional se voltou para os processos didáticos e começou a se envolver com questões que se preocupavam em vincular diretamente a Didática com o uso dos meios, afirmando categoricamente que esses estavam a serviço da Didática. Em que pese a área da Tecnologia Educacional ter seu valor e relevância, não é nesse contexto que estou propondo essa discussão.

Especificamente dentro do campo da Didática, Oliveira (1999) publicou um artigo em que ela procurou identificar os três grandes eixos pelos quais as discussões da Didática se relacionam com a Tecnologia, e o faz colocando-os como hipóteses, as quais gostaria de apresentar para poder delimitar ainda mais a área na qual estou propondo a discussão. Oliveira (1999) identifica que uma das posições que defende o uso das Tecnologias na educação ${ }^{1}$ é o que ela vai chamar de Hipótese do modelo de competência, a qual argumenta que, em face das mudanças significativas da base produtiva, estruturada em torno da tecnologia digital, a sociedade atual exige um trabalhador com novos requisitos, inclusive domínio dos códigos da informática, além de outras questões, e que, portanto, a partir do atual estágio do desenvolvimento tecnológico, os processos didático-pedagógicos não poderiam ficar atrasados. Nesse eixo de argumentação fica explicito o papel da escola como formadora para 0 
mercado de trabalho e a tecnologia acaba se tornando conteúdo para uma formação nesse sentido somente.

A outra posição apresentada pela autora como hipótese é aquela que muitos educadores defendem de que as tecnologias só não são mais utilizadas por falta de condições objetivas e de preparo dos professores para o uso adequado das mesmas, e a defesa se apóia na idéia, ou melhor, na ilusão, como diz a autora, de que os recursos tecnológicos possuem um valor acima de suas possibilidades de influência na melhoria da qualidade do processo ensino-aprendizagem. Ou seja, a importância de se incorporar os recursos (em particular as Tecnologias digitais) reside na crença de seu poder de interferir no processo qualificando-0, a tecnologia é vista como uma panacéia para os problemas educacionais brasileiros. E a terceira, e última hipótese apresentada pela autora, é a da Tecnologia Educacional Revisitada, em que se "...busca efetivar um processo educacional com, da, e para a Tecnologia." Nesse caso o uso das novas Tecnologias é tomado apenas como recurso didático, o que mostra um alinhamento com as discussões do campo da Tecnologia Educacional e do "...resgate da importância da Tecnologia educacional, tal como defendida pelo tecnicismo pedagógico, mas tratada, agora, de forma diferente." (OLIVEIRA, 1999, p. 154 -155)

Em que pese à importância dessas discussões, também não é nesse contexto que gostaria de dialogar com a Didática e/ou Tecnologia.

Primeiramente, a questão: de que se ocupa a Didática? Sobre a ação docente, suas práticas, das filosofias que orientam essas práticas, dos sujeitos dessa prática, das condições sócio-históricas em que se constroem essas práticas. Se for lícito pensar que é disso que trata a Didática, cabe-me, então, apresentar alguns conceitos centrais para minha argumentação. Em primeiro lugar, quanto ao próprio conceito de Tecnologia: estou tomando por Tecnologia

...como modo de produção, como a totalidade dos instrumentos, dispositivos e invenções que caracterizam a era das máquinas, é assim, ao mesmo tempo, uma forma de organizar e perpetuar (ou modificar) as relações sociais, uma manifestação do pensamento e dos padrões de comportamento dominantes, um instrumento de controle e dominação.(MARCUSE, 1999, p. 73)

Tomar a Tecnologia nesse sentido significa trazer para a discussão uma leitura da sociedade, a qual ainda que altamente tecnologizada, mantém as relações sociais atreladas à exploração, à dominação, pois toda tecnologia desenvolvida e organizada por um sistema social que coloca a vida do sujeito como um meio, como um apêndice da máquina como já dizia Marx, e não 
com um fim, caminha em sentido contrário ao próprio projeto da humanidade, da racionalidade, que tinha, por princípio primeiro, a felicidade humana. Se isso deixou de ser o fim primeiro e último dessa sociedade, temos que questionar o sentido do progresso e do desenvolvimento da ciência (razão) e da tecnologia (ação). Podemos começar a colocar a questão questionando uma produção material, tecnológica - da qual participamos - que não pergunta por suas finalidades, não critica a si mesma e que tem trazido resultados sociais catastróficos e fantásticos. Tenho clareza de que essa é uma questão bastante complexa, mas do meu ponto de vista, e isso foi o resultado do processo de desenvolvimento tecnológico sob a marca do capital. Os resultados desse processo são vividos por todos nós não só do ponto de vista objetivo, naquilo que interfere no nosso cotidiano, mas também, e principalmente, naquilo que interfere na nossa subjetividade, na formação de nossa personalidade, pois é como sujeito, na sua totalidade, que interagimos com esse mundo.

Já em meados do século passado, Adorno e Horkheimer (1985) alertavam que as mudanças sociais e tecnológicas que a sociedade experimentava inebriada, também imprimiam mudanças na subjetividade, no processo de formação e de individuação. A forma como as sociedades foram lidando com a dialética da satisfação dos desejos dos indivíduos e os recalcamentos necessánios para uma vida em coletividade foram estabelecendo as condições nas quais os sujeitos eram formados na sua dimensão psíquica e material. É nesse sentido que devemos pensar a Tecnologia: como expressão de uma sociedade que embute nos seus produtos a ideologia que a rege e, ao adquirirmos esses produtos, incorporamos no seu uso essa ideologia e nos colocamos a serviço da lógica do mercado, em detrimento de uma possibilidade de colocar a Tecnologia a serviço, efetivamente, de uma vida mais digna e humana.

No entanto, esse conceito de Tecnologia é bastante amplo e, para adentrar na questão em si e estabelecer a relação com a Didática, vou tomar para nossa discussão algumas em particular: aquelas que expressam seu conteúdo por meio da imagem, em particular as mídias. A TV, a fotografia, 0 outdoor, o cinema, todas elas fazem parte do nosso cotidiano, veiculando imagens as quais vêm assumindo um papel central na formação do indivíduo, pois são imagens que têm um discurso próprio. Assim como as máquinas nas fábricas impõem ${ }^{2}$ um modo de "ser trabalhador", os meios de comunicação de massa impõem um modo de "ser cidadão", de participação no espaço público, ainda que algumas delas, como no caso da TV, estejam nos espaços privados.

É nesse sentido que nos interessa discutir a imagem: como elemento do currículo, como conteúdo veiculado no interior das salas de aula - mas também fora dela - como leitura de mundo, e que constituem instâncias for- 
madoras do sujeito, e, portanto, dividem, com a linguagem (escrita ou falada), os encaminhamentos dados aos processos de ensino-aprendizagem e, direta ou indiretamente, está embutida nas práticas docentes, às vezes, sem reflexão ou conhecimento sobre seu conteúdo. Isso porque um conteúdo veiculado por meio de uma imagem, ainda que encontre suporte na linguagem, tem uma gramática própria, atua sobre o sujeito de forma diferente, como diz Aumont (1995), toma o sujeito na sua totalidade.

Essas imagens em seus suportes, se as entendermos como produções humanas, fazem parte da nossa formação, como afirma Benjamin, interferem na estruturação do nosso aparelho perceptivo. Dessa forma, podemos pensar que nós nos constituímos psiquicamente como sujeitos, sociologicamente como cidadãos sendo profundamente marcados pelas imagens veiculadas pelas mídias que intermedeiam a nossa relação com o espaço e com os grupos sociais nos/com os quais interagimos. Uma boa parte do que é produzido e veiculado pelas mídias está submetida à lógica da Indústria Cultural: o que se busca é o lucro. Nesse contexto, os apelos que ela faz aos seus consumidores emergem substancialmente dos aspectos subjetivos reprimidos pela sociedade. A forma como as mídias atuam sobre o sujeito é totalizante, no sentido lato do termo. Quer absorvê-lo, quer introduzi-lo num mundo fantasmagórico de imagens que se sobrepõem umas às outras, sem possibilidade de reflexão sobre seu conteúdo. Sem tempo para pensar. Mesmo porque, hoje muitas pessoas quando se imobilizam perante uma mídia tudo que elas querem é não pensar. Se elas puderem repetir o que vêem e escutam para manter-se integradas no contexto, já é suficiente para lhes garantir um lugar no meio que convivem. Conhecer qual pintor é o expoente do momento, qual o filme que ganhou o Oscar, muito mais do que apreciar seu conteúdo e sua expressão plástica, 0 que realmente importa para uma boa parcela da população é somente do nome para se manterem informadas, para terem o que falar nas rodas de batepapo.

A imagem, constituinte de nossa formação, remonta a períodos antigos de nossa história. Desde o tempo das cavernas, com as inscrições rupestres, até os dias atuais com a pintura, a fotografia, a televisão, o cinema, a internet no espaço privado e no público, as mídias trazem imagens que nos informam sobre pessoas, lugares, processos sociais, e acabamos por absorvêlas utilizando-as na condução de nossas ações. Em função do crescente uso das imagens na construção de nossa percepção sobre o real, interferindo na forma como atuamos no real, Huygue (1986) chegou a propor que a denominação da civilização moderna passe de Civilização do Livro para Civilização da Imagem, devido à sua presença em todas as dimensões da vida humana da pintura à realidade virtual, é a imagem que fala, mas sem sempre dentro de um código de ética que necessariamente privilegia o bem-estar humano. Em 
boa parte das imagens publicitárias, por exemplo, os interesses são econômicos, o que se pretende é vender o produto, seja ele necessário ou não, traga ele as conseqüências que for.

A partir desse contexto e dado que as experiências formativas por meio da imagem é algo dado, real e comprovado, gostaria de retomar alguns aspectos que considero relevantes para pensar a Educação, e em particular a Didática, no curso desses acontecimentos.

A questão central que proponho retomar é o conceito de experiência de Dewey $(1965 ; 1971)$. E por que? Por que se tomo como eixo a questão da formação do sujeito, essa não acontece no vazio, mas por meio, com, e pela experiência. Mesmo sabendo que inúmeros outros autores trabalharam esse conceito e ainda o fazem, como Paulo Freire, com o profundo respeito que tenho por sua obra, vou tomar as elaborações de Dewey porque as considero fecundas para a época em que foram formuladas, originais, e que orientam muitas das propostas atuais para a educação, com outras denominações, mas que têm no pensamento desse autor muitas das suas raízes. Dewey (1971) considerava que pensar filosoficamente a educação, a nova educação que ele propunha pressupunha estabelecer uma relação íntima entre as nossas experiências com o real e a educação. Porém, para ele não bastava perceber essa relação, mas "que relação era essa”, "...descobrir a relação que realmente existe dentro da experiência entre as realizações do passado e os problemas do presente".(DEWEY, 1971, p. 11)

Essa preocupação se colocava para ele porque ele rejeitava a idéia de que o conhecimento do passado devesse, ou pudesse se tornar o fim da educação, mas deveria ser somente o meio utilizado pela educação para formar as gerações. Certamente, Dewey esteve comprometido com uma filosofia empírica e experimental, pois ele, assim como William James e Charles Sanders Peirce, foram os fundadores do Pragmatismo de filiação estadunidense.

Contudo, para além dessa sua filiação, Dewey estava preocupado com uma questão filosófica que nos é muito cara: com a formação do caráter, dos valores, de sujeitos capazes de construir e de conviver numa sociedade democrática. Essas preocupações, apesar de considerar que a democracia na sociedade atual está profundamente comprometida, são questões que se colocam ainda mais urgentes e complexas, dadas as condições atuais.

Um outro aspecto do pensamento desse autor que nos parece fecundo é a idéia de que nem toda experiência é educativa. Para ele, algumas poderiam inclusive levar à insensibilidade, principalmente aquelas que ele via acontecerem na escola tradicional de sua época, por isso a necessidade de se pensar numa filosofia de, por e para a experiência. Mas o problema era definir quais experiências eram ou não educativas (DEWEY, 1971). Quem as julgaria? A partir de quais critérios? Defrontando-se com tais questões, Dewey coloca 
dois princípios para orientar, educacionalmente falando, as experiências que deveriam ser estimuladas, reforçadas, ou seja, dois princípios para valorar as experiências no interior da escola e que, de alguma forma, repercutiriam na formação do sujeito.

O primeiro princípio é o de continnum experiencial, como critério de discriminação, cujo uso deveria se dar a partir de uma prática democrática e humanista, mas principalmente perguntando-se "porque" determinada experiência é educativa ou não. Nós somos o resultado de nossas experiências. Para ele:

Toda teoria, que assume não se poder dar importância aos fatores objetivos sem impor controle externo e sem limitar a liberdade individual, baseia-se afinal na noção de que experiência somente é verdadeiramente experiência, quando as condições objetivas se acham subordinadas ao que ocorre dentro dos indivíduos que passam pela experiência. (DEWEY, 1971, p. 33)

Nesse trecho, ele nos alerta no sentido de que a experiência não tem somente importância do ponto de vista individual de cada um de nós, mas também não tem importância pensarmos nela na sua dimensão coletiva. Desse ponto de vista, a importância desse conceito para pensarmos a sociedade atual e aquilo que norteia as ações dos sujeitos, ou mesmo, o que orienta a formulação de políticas, e finalmente, o que constitui o conteúdo veiculado pelas mídias, no tipo de comportamento e experiência que são estimulados e reforçados.

O segundo princípio proposto por Dewey, para definir qualitativamente as experiências do ponto de vista do seu caráter educativo, é o de interação para interpretar uma experiência, sua função e sua força educativa. Para ele, situação e interação são dois conceitos indissociáveis para definir uma experiência, porque é o núcleo, por se tratar de uma transação que ocorre entre um indivíduo e o seu tempo e espaço (DEWEY, 1971, p. 44). Como ele dizia: "Vivemos sempre no tempo em que estamos e não em um outro tempo, e só quando extraímos em cada ocasião, de cada presente experiência, todo o seu sentido, é que nos preparamos para fazer o mesmo no futuro".

O conceito de interação, nesse sentido, coloca o movimento no pensamento de Dewey, traz a complexidade do real e a importância de tomarmos os conhecimentos científicos acumulados como meras fórmulas, fatos e regras a serem aprendidas, mas coloca esses conteúdos no interior de um processo dinâmico de perceber sua historicidade e conseguir articular com o tempo presente, visando não ao agora, mas um futuro, e certamente, como herdeiro do pensamento racionalista, um futuro melhor para a humanidade. Nesse sentido, podemos pensar, e questionar, em termos de que tipo e quais as conse- 
qüências das experiências que nossos alunos estão tendo cotidianamente com esse vastíssimo mundo da informação e da comunicação, com um mundo construído "à imagem e semelhança" do oposto do ideal de indivíduo autônomo e livre que veio sendo formulado durante séculos pelo movimento da ilustração.

Esses dois princípios para definir qual experiência é educativa ou não - continnum e interação - mostram a filosofia no qual apoiava sua proposta para a educação, e no próprio conceito de experiência é latente que ela se dá entre sujeitos em processo de formação por toda a vida, é dinâmico, é histórico e é social. Certamente, que essas breves palavras não esgotam toda a discussão em torno da questão na obra do autor, mas esse núcleo nos coloca duas questões a pensar: primeiro a de que a experiência enquanto modo de existência está no centro do processo formativo, o que é corroborado por Adorno (1995) como crítica a sociedade atual e o modo pela qual ela coloca o sujeito numa condição de desumanização, de barbarização, dificultando que se estabeleçam vínculos afetivos na constituição da própria sociedade, ou seja, do coletivo. E Adorno vai indicar também que as experiências formativas que a sociedade atual tem privilegiado, ou permitido ao sujeito, em particular no interior das escolas, se organizam muito mais para submeter o sujeito a experiências de "ajustamento" à sociedade atual do que de constituição de sua autonomia. Oliveira (1999) na sua discussão em torno da Tecnologia, já alertava para essa concepção de educação e, em conseqüência, de tecnologia atrelada a um projeto de sociedade cuja relação de exploração que a mesma imprime não está na pauta de discussões em torno da relação Educação e Tecnologia, e a escola, antes de ser um lugar de emancipação, coloca-se como um lugar de ajustamento.

Mas, para focalizar melhor nossa questão, gostaria de centralizar nossa discussão em torno da experiência que o sujeito estabelece com a imagem, e não com qualquer imagem, mas com aquelas produzidas pelas mídias. Para iniciar esse tema, retomo um outro autor que vem sendo considerado, por alguns, como um teórico que pensou no século XX o século XXI: Guy Debord. Ele, com o objetivo de fazer uma crítica feroz à sociedade atual, vai denominá-la de "Sociedade do Espetáculo". Para Debord (1997), a "Sociedade do Espetáculo" é muito mais do que os shows das mídias, para ele "...toda a vida das sociedades nas quais reinam as modernas condições de produção se apresenta como uma imensa acumulação de espetáculos. Tudo o que era vivido diretamente tornou-se uma representação". (1997, p. 13).

Aqui se torna interessante pensarmos o conceito de experiência de Dewey no contexto atual, a partir da leitura que ele - Debord (1997) - faz da sociedade. As experiências que os sujeitos tinham com o espaço e com 0 tempo, com o outro e consigo próprio, tornam-se espetáculos; no sentido de 
que não se afirmam no real, mas em representações que se erigiram sobre 0 real. Adorno vai compreender esse processo a partir da idéia de que sob nosso olhar a sociedade colocou um "véu tecnológico" pelo qual enxergamos o mundo. Se existe um véu é porque não vemos o mundo com nitidez, mas distorcido pela ideologia que incorporamos até o mais íntimo do nosso ser: ou seja, tornamo-nos parte desse mundo representado. ${ }^{3}$

É importante ressaltar isso porque, para Debord, “O espetáculo não é um conjunto de imagens, mas uma relação social entre pessoas, mediada por imagens." (1997, p. 13) E aqui está para nós a questão central: as "experiências" que nós estabelecemos, ou pelo menos parte delas, com o outro e com o meio social, são mediadas por imagens. Nesse sentido é que colocamos que o conceito de experiência de Dewey tem uma fecundidade para pensarmos 0 momento atual, mas caberia ser revisitado à luz da sociedade atual e das críticas que existem sobre ela; isso para que possamos falar de uma educação pela experiência, como propunha Dewey (1997). Pois, assim como essa sociedade transmutou conceitos carregados de historicidade como o de liberdade, - e hoje vivemos numa sociedade em que se proclama a liberdade como sua grande conquista e é a sociedade em que menos temos liberdade, no sentido liberal do termo -, a própria noção de experiência tem que ser repensada à luz das relações que estabelecemos com as imagens que estruturam nossas relações, que formam nossa subjetividade e que nos informam sobre nosso mundo. Afinal, do que se constitui uma experiência com imagens?

\section{Mas afinal, o que é uma imagem?}

Assim como estudar a linguagem e o processo de aquisição da mesma é preocupação de inúmeros educadores e, para tanto, exige um conhecimento da linguagem, tanto do ponto de vista de sua estrutura gramatical, quanto do seu significado social e simbólico, as imagens também se constituem a partir de uma gramática visual e possuem um significado social e simbólico, portanto, é, ou pelo menos deveria ser, objeto de preocupação da Educação.

Aumont (1993), no seu estudo sobre a imagem, faz uma incursão profunda abordando desde a construção física da imagem pelo aparelho ótico, até a representação que as imagens têm para nós. Para ele, o olho e o olhar são coisas distintas. O olho é o aparelho, o suporte, o que permite 0 olhar. O olhar "...é o que define a intencionalidade e a finalidade da visão. É a dimensão propriamente humana da visão". (1993, p. 59). A partir disso, quando olhamos para algo, buscamos algo nesse olhar (ou não), mas "...só há busca visual quando houver projeto de busca mais ou menos consciente." 
(1993, p. 60). No entanto, toda imagem produzida, ou seja, incrustada num suporte material, seja ele qual for, possui uma dupla realidade, toda imagem é percebida simultaneamente como fragmento de superfície plana e como fragmento de espaço tridimensional. Isso é um fenômeno psicológico fundamental que é conhecido como dupla realidade perceptiva das imagens. Este fenômeno nos permite relacionarmos com as imagens obtendo delas informações sobre a realidade, porém uma imagem que se preocupa com a nitidez do campo visual para manter-se o mais fiel possível da realidade, mas que, mesmo assim, “...como são obtidas por uma projeção da realidade tridimensional em apenas duas dimensões, implicam perda de informação por 'compressão"'”. (AUMONT,1993, p. 66).

Nesse sentido, temos um elemento a pensar: se existe perda de informações, não só do ponto de vista psicológico, mas também objetivamente, nossas experiências com as imagens são carentes de informações e portanto, em alguma medida, estão contribuindo para uma formação problemática com o real, e porque não dizer, também com o virtual.

Segundo Aumont (1993):

Não há imagem sem percepção de uma imagem, e o estudo, mesmo rápido, das grandes características da segunda, evita muitos erros (...) na compreensão da primeira. Pois, se a imagem é arbitrária, inventada, plenamente cultural, sua visão é quase imediata. $O$ estudo intercultural da percepção visual demonstrou fartamente que pessoas que nunca passaram por esse processo têm capacidade inata de perceber tanto os objetos figurados em uma imagem, quanto sua organização de conjunto - contanto que se lhes dêem os meios para empregarem essa capacidade, ao explicar-lhe o que é uma imagem. (p. 73-74)

Nesse sentido é que se coloca a questão central que gostaria de levantar nesse texto: por essas e outras questões, é premente a necessidade da Didática começar a se preocupar com o tratamento da imagem no processo de formação docente e nas pesquisas que envolvem a prática pedagógica, pois os alunos só terão condições de fazer uma leitura crítica e autônoma de uma imagem, se souberem interpretá-la. As preocupações se tornam gigantescas a ponto de nos preocuparmos com ela, porque, segundo Aumont (1993), um dos elementos centrais e constituintes das imagens é a “...vinculação da imagem em geral com o domínio do simbólico, o que faz com que ela esteja em situação de mediação entre o espectador e a realidade." (1993, p. 78). Ou seja, retomando Adorno (1995) e Debord (1997), a imagem está na sociedade atual no centro das relações sociais, portanto, da formação de nossa subjetividade, da formação do sujeito. A relação que estabelecemos com o real está sendo, 
em alguma ou em grande medida, mediado por uma "simulação", ou como diz Debord, por meio de um "simulacro".

Nesse sentido, o valor que uma imagem possui em relação com 0 real pode ser, a partir das reflexões de Rudolf Arnhein apud Aumont, (1993, p. 78), basicamente de três formas:

1) Como um valor de representação: a imagem representativa é a que representa coisas concretas;

2) Como um valor de símbolo: a imagem simbólica é a que repre senta coisas abstratas, definida pragmaticamente pela aceitabilidade social dos símbolos representados e;

3) Como um valor de signo: uma imagem serve de signo quando representa um conteúdo cujos caracteres não são visualmente refleti dos por ela.

E não só quanto ao seu valor, mas a função que as imagens ocupam na relação que estabelecemos com o real, sem pretender esgotar toda a gama complexa de relações possíveis, pode ser entendida a partir de três modos: a) Simbólico: servindo como símbolos sociais (Exemplo: as imagens divinas, na antiguidade); b) Epistêmico: trazendo informações visuais sobre 0 mundo. Aqui certamente, repousa uma questão geradora de muita polêmica, pois também sabemos que as imagens produzidas do/sobre o mundo são produtos de ações intencionais, permeadas pela relação que o sujeito produtor tem com 0 mundo e com a própria imagem produzida, por exemplo, a imagem que um fotógrafo faz de um fato não está isenta da leitura que esse sujeito tem do mundo, do fato em si e da interpretação que ele fez daquele fato. E por último, c) Estético: uma imagem é destinada a agradar (ou impressionar, ou opor-se) a seu espectador, oferecendo-lhes sensações específicas. A partir dessas considerações é que Aumont (1993) vai afirmar que "O espectador constrói a imagem, a imagem constrói o espectador" (p. 81), ou seja, é preciso entender o espectador como parceiro ativo da imagem, emocional e cognitivamente, e esse processo se dá fundamentalmente pelo reconhecimento. Segundo o autor:

Reconhecer alguma coisa em uma imagem é identificar, pelo menos em parte, o que nela é visto com alguma coisa que se vê ou se pode ver no real. É, pois um processo, um trabalho, que emprega as propriedades do sistema visual. (...) esse trabalho de reconhecimento, na própria medida em que se trata de re-conhecer, apóia-se na memória ou, mais exatamente, em uma reserva de formas de objetos e de arranjos espaciais memorizados: a constância perceptiva é a comparação incessante que fazemos entre o que vemos e o que já vimos. (AUMONT, 1993, p. 82, grifos nossos) 
Se hoje nossas relações são mediadas por imagens, a constância perceptiva com que nossa memória vem se constituindo está muito mais fortemente alicerçado nas imagens que recebemos dos mais variados meios do que das experiências ou da linguagem (escrita ou falada), e, portanto, como afirma Debord (1997), nossa vida acaba tornando-se nada mais do que um conjunto infinito de espetáculos com os quais "pensamos estar" no mundo e "pensamos ser" no mundo.

O sentido que as imagens vão tendo na constituição de nossa subjetividade caminha entre o percebido e o nomeado. Como diz Aumont (1993):

A representação do espaço e do tempo na imagem é quase sempre, portanto, uma operação determinada por uma intenção mais global, de ordem narrativa: o que se trata de representar é espaço e tempo diegéticos, e 0 próprio trabalho da representação está na transformação de diegese, ${ }^{4}$ ou de fragmento de diegese, em imagem. (p. 248)

Isto posto, todo tempo e espaço construído diegeticamente é determinado pela aceitabilidade social, pelas convenções estabelecidas, pelos códigos e símbolos que opera em uma dada sociedade e que os sujeitos pertencentes a ela apropriam como suas essas convenções, ou seja, que foram incorporadas na sua subjetividade. Pois, como salienta Aumont (1997):

Toda representação é relacionada por seu espectador (...) a anunciados ideológicos, culturais, em todo caso simbólicos, sem os quais ela não tem sentido. Esses enunciados podem ser totalmente implícitos, jamais formulados: nem por isso são menos formuláveis verbalmente, e o problema do sentido da imagem é, pois o da relação entre imagens e palavras, entre imagem e linguagem. Ponto bastante estudado, do qual vamos só lembrar que não há imagem "pura", puramente icônica, já que para ser plenamente compreendida uma imagem necessita do domínio da linguagem verbal. ( $p$. 248)

A questão que nos é colocada, como educadores, é de comparar a maneira como a imagem e linguagem veiculam as informações e como são compreendidas pelos espectadores, no nosso caso, pelos nossos alunos em sala de aula. Uma imagem só tem a dimensão simbólica porque é capaz de significar alguma coisa sempre em relação com a linguagem verbal, que por sua vez, está inserida num contexto sócio-histórico e cultural. Assim como a Didática se preocupa, não só, mas em particular, com a prática docente no sentido de pensar uma forma de nossos alunos terem uma melhor aprendizagem dos conteúdos expressados pela linguagem, nada mais sensato começarmos a refletir, no campo da Didática, a melhor forma de trabalhar com a 
imagem, no sentido de buscar uma autonomia do sujeito perante o conteúdo veiculado pelas mesmas, pois,

Se a imagem contém sentido, este tem de ser "lido" por seu destinatário, por seu espectador. é todo o problema de interpretação da imagem. Todos sabem, por experiência direta, que as imagens, visíveis de modo aparentemente imediato e inato, nem por isso são compreendidas com facilidade, sobretudo se foram produzidas em um contexto afastado do nosso... (AUMONT, 1993, p. 250).

Esse é, do meu ponto de vista, o problema que se coloca hoje na questão da relação da Didática com a Tecnologia, não com qualquer Tecnologia, mas com as mídias, e não somente na perspectiva de pensar os usos das mídias, mas de voltar-se para as questões que envolvem os conteúdos que essas mídias veiculam utilizando para tanto as imagens.

São inúmeros os países que já demonstravam preocupações quanto ao papel formador da mídia no público infanto-juvenil. Alguns países, particularmente europeus ou de língua inglesa, vêm desenvolvendo trabalhos nessa área há várias décadas, e mais recentemente alguns países de língua espanhola. Sem a intenção de esgotar todas as experiências, gostaria de citar alguns países tendo em vista a proposta que apresentaram de Educação para as Mídias.

\section{A Educação para as mídias}

O relato que trago aqui tem por função mostrar que as questões que estamos propondo discutir têm uma trajetória e, portanto, não há intenção de fazer comparações entre as experiências, ou avaliações de programas, mas sim o intuito somente de situar a questão, principalmente da educação brasileira, em relação a outros países.

Os trabalhos nas escolas de educação para as mídias no Canadá tiveram início nos anos 60, mas foi somente no final da década de 90 que foi incorporado como obrigatoriedade nos currículos de artes e língua inglesa. Para amparar os trabalhos dos professores foi elaborado um documento pelo Ministério da Educação com conceitos-chaves que, de certa forma, definem e delimitam os trabalhos nessa área. São eles: 1) todos os tipos de mídia são construções, 2) a mídia constrói a realidade, 3) o público negocia significados na mídia, 4) a mídia tem implicações comerciais, 5) a mídia contém mensagens ideológicas e de valor, 6) a mídia tem implicações políticas e sociais, 7) forma e conteúdo estão intimamente relacionados e 8) cada tipo de mídia tem formas estéticas particulares. 
Esses conceitos indicam que o trabalho que se pretende nas escolas canadenses vai além do instrumental, ou seja, do domínio técnico; também não coloca a ênfase somente no meio, mas particularmente no sujeito, no público que essas mídias estão formando; e tampouco coloca esse público numa posição passiva, idéia essa que era muito defendida em décadas anteriores influenciadas pelas teorias na área de comunicação sobre recepção; 0 valor e a função que a imagem ocupa no processo ensino-aprendizagem é tomado em conta, bem como, seu conteúdo ideológico e representativo. Mas, apesar da clareza quanto aos objetivos do trabalho de educação para as mídias, as escolas e professores ainda encontram diversos problemas a serem enfrentados, desde a falta de materiais audiovisuais para serem utilizados em sala de aula, até profissionais habilitados para trabalharem esses conteúdos nas disciplinas. Como aponta Andersen e outros (2002), existem experiências diferenciadas entre as províncias canadenses e isso, se por um lado traz aspectos positivos, pois respeita as particularidades das regiões, por outro, criam desníveis quanto a qualidade dos trabalhos, alguns são melhores, mais consistentes que outros.

Dessa experiência canadense, o aspecto que nos interessa são os conceitos centrais que apresentam acerca das mídias, pois ainda que possam insinuar uma visão antimídia, o desafio é como trabalhar a mídia e a educação juntos, na construção de uma sociedade melhor. Essa questão é motivo de crítica de alguns programas governamentais, pois o que acaba entrando em jogo são também os interesses econômicos e de poder de estâncias sociais. McMahon e Quin (2002) identificaram que diferentemente de algumas experiências australianas e européias, as experiências sul-americanas têm se fundado muito mais na cooperação, porque “...baseiam-se no conhecimento de que ambos os grupos [escola e meios de comunicação] têm muito a perder (inclusive, talvez, suas vidas) se a democracia não florescer". (p. 228). Certamente, tem-se que considerar que a questão da democracia na América Latina tem um sentido, um peso e valor bastante diferente desses países citados, portanto é necessário resguardar as diferenças históricas e culturais entre os países onde ocorrem essas experiências. Por isso é que, por melhor que esteja sendo a experiência de um dado país europeu, jamais seu modelo poderá ser trazido e implantado na realidade brasileira. Nossa trajetória, tanto a educacional, quanto à dos meios de comunicação, em particular quanto ao seu conteúdo e 0 papel que cumpre na formação sociocultural brasileira, tem que ser considerado para pensar qualquer projeto de Educação para as Mídias aqui no Brasil. De qualquer forma, os conceitos apresentados nos servem como balizas, como eixos de discussão, reflexão e análise em relação às mídias.

Já na Austrália, a Educação para a Mídia passou por várias fases. Inicialmente de inspiração crítica, passou mais recentemente a atrelar seus 
interesses aos dos meios de comunicação que, praticamente, está monopolizado no país em duas grandes empresas de comunicação. Formalmente, nas décadas de 70 e 80 existia uma área, ou setor, com professores com formação específica para a educação para as mídias. Atualmente, o que vem acontecendo é o país incorporar esses estudos aos da língua materna, ao das artes e numa área denominada Tecnologia e Empreendimento. A crítica que McMahon e Quin (2002) apresentam é que essa mudança de eixo vem prejudicando a constituição da democracia australiana, pois a Convenção da ONU dos Direitos da Criança e Adolescente vem sendo descumprida em alguns de seus itens, em particular naqueles que garantem o acesso às informações e a formação crítica para analisar as informações. A mídia tem priorizado informações que elevam seus índices de audiência e menos as informações que garantam a democracia no país. Como dizem, a mudança de ênfase do criticismo para a apreciação artística e para a produção relacionada com o mercado é óbvia e indica uma tendência ideológica que eles denominam de racionalismo econômico. Apenas a título de comentário, infelizmente esse parece ter sido, e ainda é, o elemento definidor dos conteúdos das mídias brasileiras, o nosso maior problema é que a grande maioria da população sequer tem condições de tecer esse tipo de crítica.

Nos países de língua espanhola a situação é um pouco diferenciada. A Espanha vem apresentando uma proposta de incorporação dos meios de comunicação à educação e uma crítica contundente e reflexiva sobre essa problemática. No entanto, Martín (1998), analisando a proposta da educação multimídia na Espanha, critica a proposta porque a seu ver essa problemática vem utilizando um discurso impositivo e imperativo dirigido aos educadores. Segundo ele, esse discurso, na maioria das vezes, é construído visando muito mais a uma necessidade do mercado das empresas que fabricam e comercializam tais produtos, do que uma necessidade estritamente social ou educativa. Em vários outros países sul-americanos existem programas que visam à formação de educadores para o domínio das mídias, mas, mais do que o domínio tecnológico, o que está colocado nesses programas é a necessidade de dar condições teórica e prática aos docentes para que consigam articular conteúdos curriculares com 0 uso dos meios numa perspectiva de crítica social mediante a análise dos conteúdos dos meios. Como coloca o espanhol Martín (1998, p. 4),

...si la escuela pretende seguir siendo uno de los principales agentes educativos en la sociedad futura, y no quedarse reducida a su función de guardería, será necesario que se adapte al mundo en el que los niños viven, será necesario que adopte una postura abierta, crítica y responsable con respecto a aspectos tan importantes hoy en día como los medios de difusión, las nuevas Tecnologias y la comunicación multimedia. 
Na África do Sul, a educação para as mídias (Críticos, 1998), após o fim do apartheid, tem objetivos bem claros: construir atitudes e valores os quais visam a promover a transformação da sociedade para a tolerância, para uma sociedade não racista e sexista; para a compreensão e aplicação dos direitos humanos na constituição de uma sociedade em que a crítica, a reflexão e a criatividade estejam presentes na orientação da formação dos indivíduos das novas gerações. No programa desenvolvido pelo Departamento de Educação da África do Sul consta como necessidade que os professores tenham domínio na interpretação das imagens, signos, pinturas e a linguagem não-verbal. Conforme documento do Departamento de Educação (CRITICOS, 1998, p. 9),

If this claim of a paradigm drift materialises we can expect to lose some of the hard division between media education and other disciplines as well as the hard division between the school and local community. This drift will take the critical paradigm of media education closer to concerns of human rigths and critical citizenship.

Nessa mesma perspectiva, o México vem desenvolvendo desde 1996, e coordenado pela Subsecretaria de Serviços Educativos para o Distrito Federal, o Programa de Educación para los Medios com o entendimento de que:

...para lograr formar alumnos críticos ante los medios de comunicación, es preciso que los profesores desarrollen una sensibilidad especial a través de la cual se pueda conjugar el conocimiento de los medios de comunicación con su tarea como educadores, dicha tarea es compleja y requiere concebir al profesor como un educomunicados. (RAMOS, 1998, p. 2)

Podemos perceber que está explicitada a necessidade de a escola incorporar a problemática dos meios de comunicação não como resposta ao mercado, ao contrário, no sentido de que é necessário um domínio dos conteúdos das mídias, pois são instâncias formadoras dos indivíduos em dimensões das quais não podemos desconsiderar. A perspectiva da Educação para as Mídias, como indica a sueca Graviz (1998, p. 1), é

.... discipline which incluses systematic studies of the media's importance for human development in relation to his or her individual context and conditions. (...) Media literacy means more than just reading and writing, (...) media literacy should start by considering media message as construction which create a picture of reality which contains both values and ideologies. 
Na Europa, em geral, nas últimas duas décadas houve uma mudança de enfoque, do emissor para o receptor. Como relata Tufte (2002):

...hoje há uma tendência dupla: a mídia de massa ainda é vista como poderosa, mas, por outro lado, o público é 'forte' até um determinado ponto, lembrando-se e sendo influenciado principalmente por informações e mensagens da mídia que são relevantes para sua vida diária. (p. 239)

Numa pesquisa realizada nos países do mundo que trabalham com a educação para as mídias, existem alguns fatores que se mostraram cruciais para o desenvolvimento de um trabalho que permita ao professor dominar os conteúdos veiculados pelas mídias: 1) ser um movimento originado na população e os professores tomarem a iniciativa, 2) apoio governamental, incorporando essa temática nos currículos escolares, 3) os cursos de formação de professores (licenciaturas e pedagogia, no caso do Brasil) terem profissionais habilitados para formar esses futuros professores, 4) formação continuada nessa área aos professores que estão atuando com esses conteúdos, 5) consultores especializados e materiais de apoio aos professores, 6) ter uma organização, instituição, que organize e promova eventos nessa área para dar suporte a trocas de experiências, publicações, 7) instrumentos de avaliação apropriados para tais estudos e, finalmente, 8) um clima de cooperação entre professores, sociedade civil, pesquisadores e profissionais de mídia (PUNGENTE apud ANDERSEN et al. 2002)

Esses fatores, certamente fruto da experiência de muitos países, mostram que esse trabalho requer vontade política, disponibilidade econômica e compromisso ético com a construção de uma sociedade democrática, formada por cidadãos autônomos, com identidade própria e senso estético crítico. Ainda que saibamos que a questão depende não só da educação, mas penso que essa seja uma função que a escola básica deve assumir com seriedade e compromisso político e estrutural, e que, ainda que possa ser objeto da filosofia, da sociologia, da psicologia, a meu ver, é em primeiro lugar um objeto da Didática, pois, ao final, serão no interior das salas de aula que os professores poderão fazer um trabalho de formação crítica dos conteúdos veiculados pelas mídias, das imagens de imagens que constroem um mundo fantasmagórico, nas palavras de Adorno, um mundo que só existe na ficção de uma sociedade sem rumo, sem pai e, sem humanismo.

Aqui no Brasil, muitos pesquisadores têm realizado trabalhos envolvendo as mídias mostrando um certo consenso de que os meios de comunicação audiovisuais, em particular a televisão, têm trazido repercussões para a educação. Em função disso, mostrou-se reincidente a idéia de propor uma pedagogia que suportasse atividades cujo objetivo é a de desmistificar a mídia, 
seu poder de manipulação e de persuasão. Fischer (2001a), na sua pesquisa sobre a televisão, analisa que:

A TV precisa entrar nas escolas e na formação dos professores não apenas como recurso, meio, mas também - e sobretudo - como objeto de estudo.(...) Cabe, sim, educar para uma compreensão objetiva e crítica da linguagem e das mensagens da TV. (FISHER, 2001a, p. 113)

Isso porque a:

...presença da TV na vida cotidiana tem importantes repercussões nas práticas escolares, na medida em que crianças, jovens e adultos de todas as camadas sociais aprendem modos de ser e estar no mundo também nesse espaço da cultura. (FISCHER, 2001a, p. 18)

Pretto (1996) também analisa nessa mesma perspectiva:

Não se trata de incorporar esses recursos como instrumentalidades, tampouco de se buscar uma educação para a mídia com centro exclusivo no receptor (existirá ainda receptor?!). Neste novo contexto, parece ser de fundamental importância o domínio dos processos tanto de recepção como de produção, uma vez que não basta a simples (simples?!) introdução desses meios na escola, mas sim o reconhecimento da existência de um novo logos que modifica substancialmente o fazer-educação(...). Essa aproximação [entre educação e comunicação] modificará substancialmente este fazer educação, com a escola passando a ser um centro irradiador de conhecimento e, conseqüentemente, tendo o professor um novo papel. (PRETTO, 1996, p. 20-1)

Também Rezende (1998) expõe esse mesmo ponto de vista:

Embora a TV não tenha prioritariamente função educativa, ela integra a totalidade das experiências existenciais da criança e, sem dúvida, estabelece padrões de comportamento. E o faz de forma prazerosa, enraizado no serestar-no mundo. (REZENDE, 1998, p. 73)

Ainda que muitos pesquisadores venham se debruçando sobre essa questão, muito ainda há que se compreender desse processo.

\section{Algumas considerações mais gerais}

As discussões trazidas colocam questões que, certamente, vão para além da Didática e da Educação: remetem à nossa responsabilidade como 
cidadãos e educadores na formação de um sujeito autônomo, livre, capaz de concretizar as transformações sociais que urgem na nossa sociedade. Nesse contexto, pensar a sociedade atual permeada pela mídia, e junto com ela, a própria publicidade, a qual tornou-se parte integrante da economia, é diagnosticar que ela transformou o indivíduo numa mercadoria passível de ser explorada como o cigarro, os hotéis cinco estrelas, os shampoos, como um móvel para repositório de bens que devem ser consumidos e onde devem ser colocados os penduricalhos criados pela Indústria Cultural - desde roupa, jóias, cartões de crédito, diplomas - para indicar seu potencial de consumo.

A sociedade que mais desenvolveu as possibilidades de concretizar 0 ideal liberal de indivíduo tende agora a liquidá-lo completamente. Ainda que jamais tenhamos tido um momento na história humana em que a individuação tenha se dado completamente, no período de auge do liberalismo as possibilidades se apresentavam até mesmo nas contradições que se tornavam visíveis e questionáveis. Mas, nesse século que findou e no que estamos iniciando, assistimos à tentativa de eliminar essas contradições por meio de uma ideologia que tende a mascarar e a ajustar tudo ao existente: um dos meios para isso tem sido o uso da mídia como espaço de formação com intencionalidade e intensidade. Formação que pode ser tanto para libertar o sujeito, como para aprisioná-lo a essa sociedade.

Com isso, não só a não realização do indivíduo autônomo, mas também a sua renúncia são o que permite que hoje, século XXI, uma sociedade profundamente contraditória, com altíssima tecnologia, consiga exigir das pessoas um excesso de sacrifício, que continua a destruir as potencialidades humanas e que persiste sustentado pelas próprias pessoas que sofrem suas conseqüências, mas que incorporaram a ideologia nele contida.

As contradições do sistema capitalistas não foram superadas, o que se tenta é mascará-las por meio da ideologia, a qual é fortemente sustentada e ampliada pelos meios de comunicação de massa, pelas produções culturais e artísticas, e por último, por todos e cada um que se integra ao sistema e o reproduz no seu cotidiano. Se essa clareza não se encontra no universo de pensamento e da linguagem, tudo passa a ser analisado nos termos da atualidade, do agora e do aqui dado: se liberdade é não ter liberdade, então, essa é a liberdade possível. A perda da contradição ao nível do pensamento se reflete na linguagem, pois por meio da linguagem a qual poderia explicitá-la, demonstrá-la, explicá-la e denunciá-la; acaba por se constituir num dos elementos que a nega.

Com isso, a necessidade de retomarmos as discussões em torno do domínio das linguagens, em particular da linguagem das imagens, é urgente, mas numa dimensão que permita ao sujeito libertar seu pensamento da unidimensionalidade em que o sistema social o coloca, e a única forma para tanto 
é ter autonomia de pensamento. Se estiver acontecendo o fechamento do universo da linguagem e do pensamento, isso nos desinstrumentaliza para 0 trato e a reflexão sobre o que recebemos de informação, seja ela em que formato for: texto ou imagem, e, contraditoriamente, cada vez mais temos facilitado o acesso a elas. Podemos pensar nesse fechamento de forma ampla se analisarmos a relação dos sujeitos com a mídia pela ótica da recepção, ou seja; como é possível um espectador de cinema, por exemplo, entender plenamente o discurso que vê e escuta ao ver um filme se sequer conhece os elementos que compõem esse discurso?

Esses elementos, em alguma medida, interferem na formação do pensamento e, conseqüentemente, nas ações dos sujeitos. A carência de uma ação alicerçada num pensamento reflexivo, que compreenda a contradição na sociedade, compreensão que depende dos sujeitos saberem interpretar as linguagens que "constroem" esse mundo, para que consiga "ler" os conteúdos veiculados pelas mídias e criticá-los, contribui fortemente, mas não exclusivamente, para que não ocorram as transformações sociais necessárias para nos distanciar da barbárie latente. Se em outros momentos da história essa barbárie se fez presente por meio de guerras, de governos autoritários, hoje ela se expressa em todas as sociedades de forma sutil, lenta, praticamente sem necessidade de coerção, de força física.

Quanto aos elementos apontados acima em relação ao indivíduo e à sociedade, podemos dizer que a formação que essa sociedade nos proporciona não tem levado à constituição do indivíduo. Formação, em nosso entender, seria a conquista da autonomia pelo indivíduo mediante a formação de um ego bem estruturado, capaz de lidar com as limitações que o coletivo coloca sem cair necessariamente nas malhas da integração total. E isto não é possível se a sociedade atua sobre os indivíduos limitando ou cerceando sua liberdade, sua capacidade de decidir autonomamente.

A sociedade que perpetua a contradição social, colocando cada um em contraposição ao outro porque todos têm de lutar individualmente pela sobrevivência, e mantida por uma ideologia que mascara sua dinâmica real, não permite que as pessoas se realizem conforme suas próprias determinações e,

...enquanto isto ocorre, a sociedade forma as pessoas mediante inúmeros canais e instâncias mediadoras, de um modo tal que tudo absorvem e aceitam nos termos desta configuração heterônoma que se desviou de si mesma em sua consciência. (ADORNO, 1995a, p. 181).

Essas instâncias mediadoras são também os meios de comunicação de massa, as mídias, as produções culturais que apresentam um simulacro de sociedade. É a sociedade do Espetáculo. São imagens que temos do mundo, 
dos outros, de nós mesmos. Em relação à Educação, para finalizar:

...Toda e qualquer educação política deveria centralizar-se na necessidade de impedir que Auschwitz se repita. Isso só seria possível se se pudesse tratar desse problema, o mais importante de todos, abertamente, sem medo de chocar com poderes estabelecidos de qualquer tipo. Para tanto, deveria transformar-se em sociologia, isto é, esclarecer a respeito do jogo de forças sociais que se movem por trás da superfície das formas políticas. Deveria tratar-se criticamente - apenas para fornecer um modelo - um conceito tão respeitável como o de razão de Estado: quando se coloca o direito do Estado acima do dos membros da sociedade, já está colocado, potencialmente, 0 horror. (ADORNO, 1995, p. 123)

Por conseguinte, não se trata de discutir a Didática ou a Tecnologia, mas Didática e Tecnologia.

\section{Notas}

1 Oliveira não utiliza esse conceito, mas tem sido muito usual denominar de Tecnologia educacional somente aquelas consideradas como "Novas Tecnologias", que podem muito bem ser lidas como as Tecnologias digitais e/ou interativas. Esse uso indevido, ao meu ver, do conceito de Tecnologia produz um reducionismo muito grande em torno de uma discussão que merece nosso apreço, que não é a Tecnologia em si, mas o seu conteúdo. O texto de Oliveira trata especificamente da informática, ainda que, em certos momentos, ela amplie a discussão.

2 O uso do verbo Impor é proposital apesar de sabermos que é bastante forte e não reflete necessariamente a realidade, mas foi utilizado para afirmar que a ideologia que essa sociedade engendrou se tornou tão plástica, sutil e "invisível", que, por mais que o sujeito tenha sempre a possibilidade de se contrapor a ela, o esforço físico e subjetivo é tamanho, que a grande maioria acaba por aceitar em maior ou menor medida as regras do jogo e se integrar ao sistema, alguns com, outros sem qualquer resistência. Por isso, o uso desse verbo, apesar da consciência de que a relação é bem mais complexa, tem um sentido não de coerção, mas de sedução, tal como o canto das sereias no episódio da Odisséia de Homero.

3 O conceito de representação é bastante complexo e polissêmico. Estamos tomando-o nesse texto como algo que não pode ser tomado pelo objeto em si, mas como uma representação dele, feita por um sujeito, portanto, com uma "leitura" particular desse sujeito sobre esse objeto. Faço referência a sujeito, mas podemos entender esse sujeito como alguém, uma pessoa, uma instituição, ou o próprio sistema, ou parte dele, que organiza a sociedade.

4 Segundo Aumont, "...diegese é uma construção imaginária, um mundo fictício que tem leis próprias mais ou menos parecidas com as leis do mundo natural, ou pelo menos com a concepção, variável, que dele se tem." (1993, p. 248)

\section{Referência}

ADORNO, Theodor W. Palavras e Sinais: modelos críticos 2. Tradução: de Maria Helena Ruschel. Petrópolis: Vozes, 1995. 
ANDERSEN, Neil et. al. Educação para a mídia no Canadá: a segunda primavera. In: CARLSSON, Ulla ; FEILITZEN, Cecilia Von. (Orgs). A criança e a mídia: imagem, educação, participação. São Paulo, SP: Córtex, 2002.

AUMONT, Jacques. A Imagem. Campinas: Papirus, 1993.

Papirus, 1995.

CRITICOS, Costas. Media Eduaction \& critical citizenship in South África. In: CONGRESSO INTERNACIONAL DE EDUCAÇÃO E COMUNICAÇÃO , 1., São Paulo, SP. 1998. Anais on-line... São Paulo, SP: ECA/USP, 1998. Texto disponível na internet: http://www.eca.usp.br/nucleos/nce/pdf/ congress_textos.html. Acessado em 15 mai. 2001.

DEBORD, Guy. A sociedade do espetáculo. Rio de Janeiro, Ry: Contraponto, 1997.

DEWEY, John. Vida e Educação. 5. ed. São Paulo, SP: Melhoramentos, 1965. . Experiência e Educação. São Paulo, SP: Nacional, 1971.

FISCHER, Rosa Maria Bueno. 2001. Uma análise foucaltiana da TV: das estratégias de subjetivação na cultura. In: REUNIÃO ANUAL DA ANPED, 24., 2001, Caxambu. Anais... Caxambu, 2001. p. 97-115. (Grupo de trabalho Educação e Comunicação - GT16).

Televisão \& Educação: fruir e pensar a TV. Belo Horizonte: Autêntica, 2001.

GRAVIZ, Ana. 1998. Media Education as a discipline. In: CONGRESSO INTERNACIO NAL DE EDUCAÇÃO E COMUNICAÇÃO, 1., SãoPaulo, SP. 1998. Anais on-line... São Paulo, SP: ECA/USP,1998. Texto disponível na internet: http:// www.eca.usp.br/nucleos/nce/pdf/congress_textos.html. Acessado em 15 maio 2001.

MCMAHON, Barrie ; QUIN, Robin. As crianças australianas e a Mídia Educação, Participação e Divertimento. In: CARLSSON, Ulla; FEILITZEN, Cecilia Von. (Orgs.). A criança e a mídia: imagem, educação, participação. São Paulo, SP: Cortex; 2002.

MARCUSE, Herbert. Algumas implicações sociais da tecnologia moderna. In: KELLNER, Douglas (ed.). Tecnologia, guerra e fascismo. São Paulo, SP: UNESP, 1999. p. 73-104. 
MARTÍN, Alfonso Gutiérrez. 1998. Educación multimedia: una propuesta desmitificadora. In: CONGRESSO INTERNACIONAL DE EDUCAÇÃO E COMUNICAÇÃO, 1., SãoPaulo, SP. 1998. Anais on-line... São Paulo, SP: ECA/ USP, 1998. Texto disponível na internet: http://www.eca.usp.br/nucleos/ nce/pdf/congress_textos.html. Acesso em 15 maio 2001.

OLIVEIRA, Maria Rita N. S. Tecnologias interativas e educação. Educação em Debate, Fortaleza, v. 21, n. 37, p. 7-25, 1999.

PRETTO, Nelson de Luca. Uma escola sem/com futuro: educação e multimídia. Campinas, SP: Papirus, 1996. (Coleção Magistério: formação e trabalho pedagógico).

RAMOS, Alexandrov Vladimir Peña. 1998. Apropriación y uso de los médios de comunicación en el aula: el profesor como educomunicador. In: CONGRESSO INTERNACIO NALDE EDUCAÇÃO E COMUNICAÇÃO, 1., SãoPaulo, SP. 1998. Anais on-line... São Paulo, SP: ECA/USP,1998. Texto disponível na internet: http://www.eca.usp.br/nucleos/nce/pdf/congress_textos.html. Acesso em 15 maio 2001.

REZENDE, Ana Lúcia Magela de. Televisão: babá eletrônica? In: PACHECO, Elza Dias (Org.). Televisão, criança, imaginário e educação. Campinas: Papirus, 1998. p. 71-82.

TUFTE, Birgitte. A educação para a mídia na Europa: com foco nos Países Nórdicos. In: CARLSSO N, Ulla; FEILITZEN, Cecilia Von. (Orgs.). A criança e a mídia: imagem, educação, participação. São Paulo: Córtex, 2002.

VERMELHO, Sônia Cristina. Algumas reflexões em torno da tecnologia como expressão da subjetividade. In: LEITE, Márcia \& FILÉ, Valter (Org.). Subjetividade, tecnologia e escolas. Rio de Janeiro, RJ: DP\&A, 2002. (Coleção O sentido da escola).

. Educação e virtualização: as mídias e a formação do indivíduo. São Paulo, 2003. Tese (Doutorado. Programa de Estudos Pós Graduados em Educação: História, Política e Sociedade) - SPPUCSP, São Paulo, SP. 2003.

PURIFICAÇÃO, Ivonélia. 2000. Informática na educação: a percepção dos docentes. In: Tuiuti: Ciência e Cultura, n 16, mar. p. 119-134.

1998. A subjetividade do trabalhador no contexto da produção integrada e flexível. São Paulo, PUC-SP, 1998. Dissertação de mestrado. Programa de Estudos Pós-Graduados em Educação: História, Política e Sociedade. 